\title{
Wooden Grave Posts of the Hungarians: A Hungaricum
}

\author{
László Ferenc Novák \\ Arany János Muzeum, Nagykőrös, Hungary
}

\begin{abstract}
The wooden grave-marker cult, which has evolved in the Protestant burial ritual, is characteristic of the Hungarian folk culture. Protestantism took root in the middle of the 16th century and its Calvinist branch, that became a Hungarian religion at the age of Turkish subjection, guaranteed the survival of the Hungarian nation. Protestants did not use crosses as grave-markers; they set up carved wooden posts instead of them from the end of the 17th century. The system of decorative elements illustrates the ancient culture of the Hungarians. This is proper anthropomorphism: The primary statue set up on the grave mound symbolizes human life and a secondary manifestation of it, i.e., a sphere motif symbolizes the human head; the trunk is decorated with star-, tulip-, and ring-shaped and even jardinière motifs. These decorative carvings change the carved wooden grave post into a "tree of life symbol". The grave post cult of Protestant folk art flourished at the end of the 19th century and at the beginning of the 20th century. The use of "wooden headboards" and the masterpieces of folk art have spread since the middle of the 20th century. The decoratively carved wooden headboards were decorated with the decorative motifs on the wooden head posts. Wooden headboards appear at historical memorial places throughout the country and they symbolize various historical events. However, they are not identical with the wooden grave posts, which are the local specific manifestations of folk art: They are Hungaricum.
\end{abstract}

Keywords: grave-markers, carved wooden grave posts, wooden headboard as national commemorative post, tree of life, Hungaricum

\section{Introduction}

The carved wooden grave post is a characteristic of the Hungarian Protestant (Calvinist, Unitarian, and partly Lutheran) cemeteries. After the funerary liturgy, a simple or an exuberantly carved wooden post is erected on the head side of the grave, which is not simply a wooden post but it is a fancy wood carving whose system of motifs is anthropomorphic and an iconic replica of the human body. As the manifestation of authentic folklore, it is a characteristic and imposing representative of folk art.

Different designations are used for carved wooden grave posts in various areas of the country, like "fejfafejefa"(Transtibiscan territory, Upper-Hungary), "fötöl-fütülvalófa" (Szilágyság-Transsylvania), "gombosfa" (the Danube-Tisza interfluve), "gombfa" (Kalotaszeg, Háromszék-Transsylvania), "epitafa" (Ordas-territory near the River Danube), "sögfa" or "süveg-fa" that refers to the headgear of a man (Örség一the South-Western part of Transdanubia) (Kós, 1972; Novák, 2005, 2011). The carved wooden grave post is not merely a simple grave-marker but it is also an imposing objectivised memory of folk carving art. Although the reformation had spread in Hungary in the middle of the 16th century, Protestant grave-markers (other than crosses) appeared

Prof. Dr. László Ferenc Novák, DSc (Doctor of Hungarian Academy of Science), honorary director of the János Arany Museum, honorary president of the János Arany Society, Nagykőrös, Hungary. 
only in the 17th century. Historical data prove their existence. The forms and ornamentation of wooden grave posts developed as late as in the 19th century. Their range of motifs used in ornamentation preserves archaic elements, which recall the ancient culture of the Hungarians.

\section{Locations and types of wooden grave posts}

The earliest historical data on grave-marking come from the Calvinist town Nagykörös (Pest County). The Protestant city council (body of magistrates) had their Reformed preacher buried in 1638. The list of expenses indicates that lath nails were bought to fasten the timbers which covered the sepulchral mound or to set up a wooden fence around it ("Léczszöget vettünk, hogy az predicator temetésit felróttuk fával" - Archives of the National Archives in Pest County, Books of Accounting of the town of Nagykörös 1637/38). This is a peculiar form of grave-marking. In Karelia where the Finns live (the Finns and the Hungarians are related nations), the funeral ritual was similar to this even at the turn of the 19th to the 20th century. The sepulchral mound was covered with timber and on the head-side a cross or a wooden grave post was set up according to the religious affiliation of the diseased person (Koczogh, 1979). According to some researchers, the timber covering of the mound or perhaps a boat laid over the mound upside-down appear also in the ornamentation of wooden grave posts. This can be considered as the ancient-millennial-heritage of the Hungarians from the Ugrian period. In the tundra region, the dead body was carried to the burial-place by boat and the boat was laid over the mound upside-down. A late memory of this can be seen in Szatmárcseke (Upper Region of the River Tisza, Szatmár region): The boat-shaped grave-marker set up upright looks like a moustached human figure (Solymossy, 1930).

The large-sized/bulky wooden grave posts in Szatmárcseke have anthropomorphic forms (see Figure 1). They seem to visualize a human face with "moustache" ornamentation. Similar grave posts occur also in other places. 


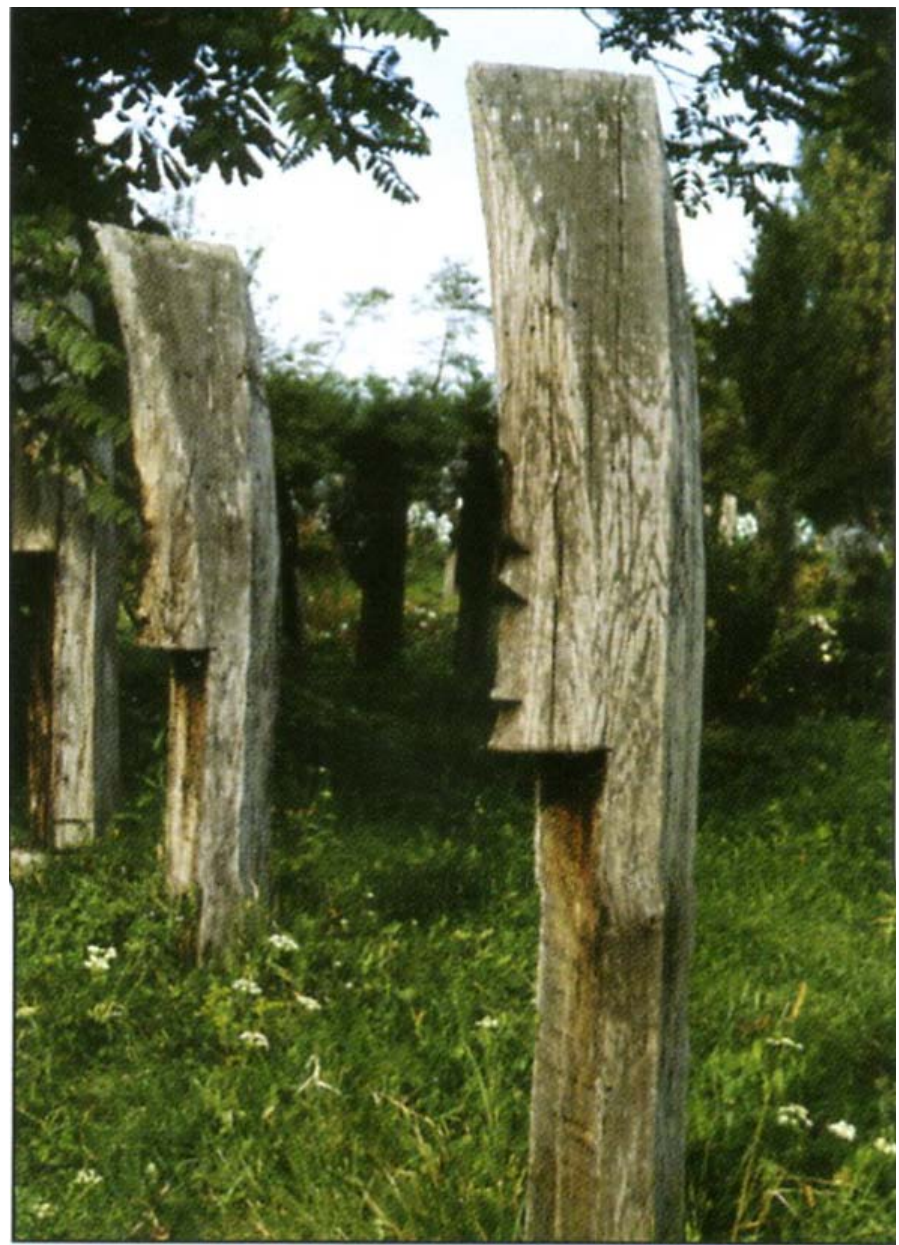

Figure 1. Wooden grave posts-Szatmárcseke.

Anthropomorphic wooden grave-markers can be considered the most archaic. The human figure appears either as a human being or as a conventional form; it is a symbolic man-statue. The most beautiful samples are to be found in the towns Dunapataj, Tószeg near the River Tisza and in Békés, Hódmezővásárhely in the Körös-Tisza interfluve. (see Figures 2-5). 


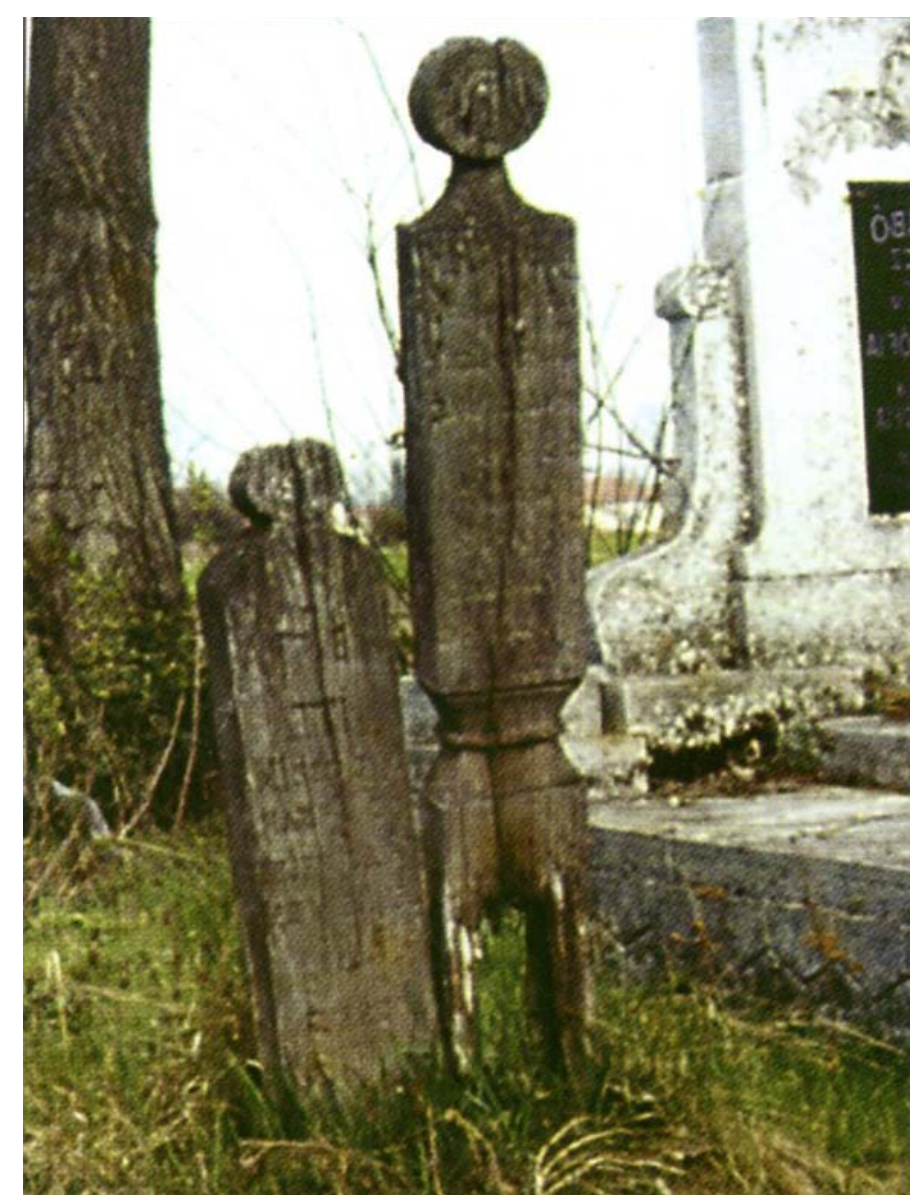

Figure 2. Grave posts (mother and her son)-Békés. 


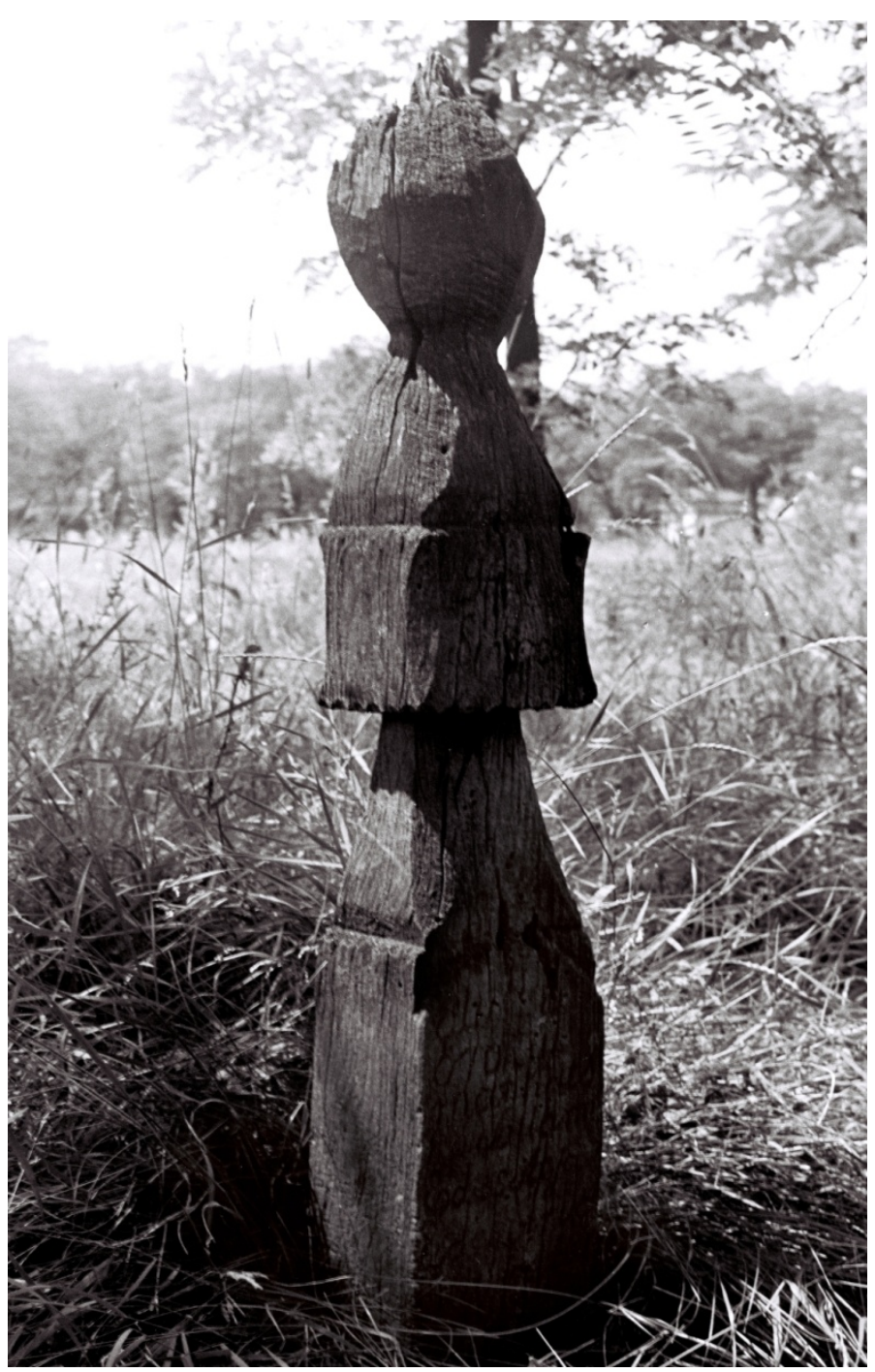

Figure 3. Grave post of a woman-Tószeg. 


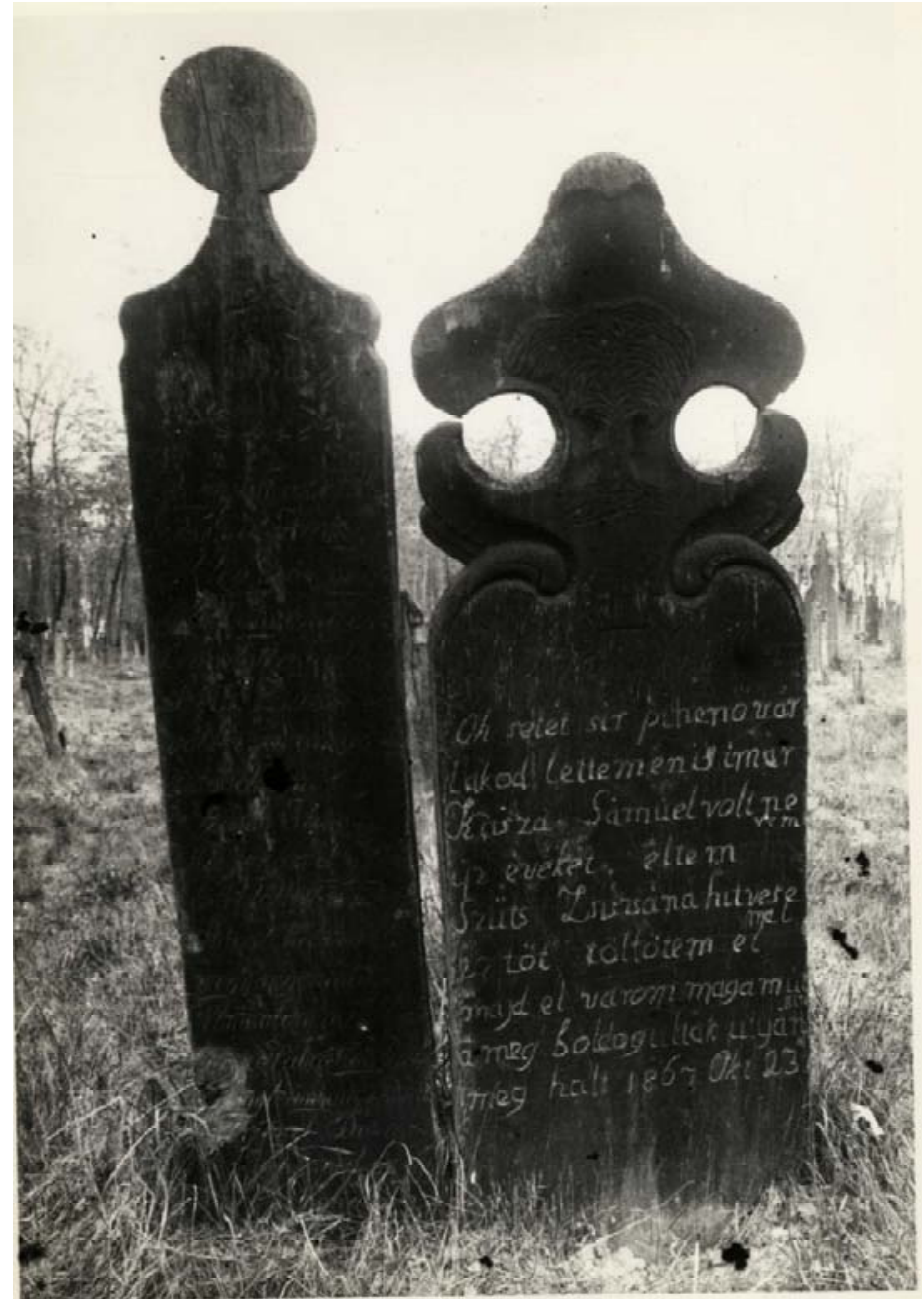

Figure 4. Grave posts (husband and wife) -Hódmezővásárhely. 


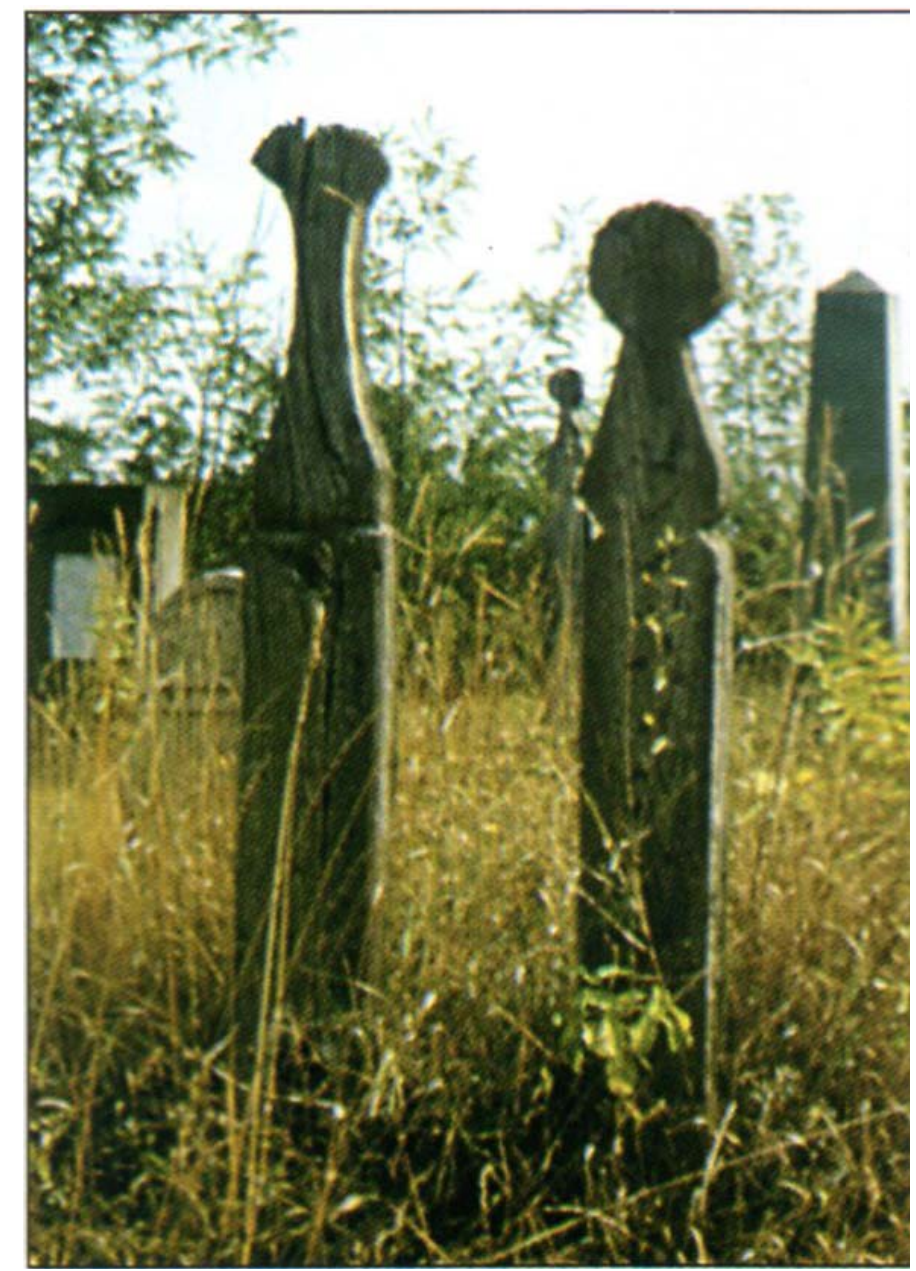

Figure 5. Grave-markers of a married couple (husband and wife). Kunszentmiklós.

Another group of grave posts consists of conventional and anthropomorphic wooden images, which end in a narrow roundish shape, the so called "knob grave-markers (in Hungarian "gombosfa" or "gombfa"). Anthropomorphism is expressed through knob-ball or ring shaped ornamental elements, symbolizing the human head and trunk (see Figures 6-10) (Novák, 1982; 2005;2015).

The habit of setting up wooden grave-markers spread slowly in the 18th century. Religious restlessness and hostilities hindered their application in regions where there was a Roman Catholic majority or where the feudal lord was Catholic (cuiusregio, eiusreligio). The Patent of Toleration (Edictum Tolerantiae) issued in 1781 by the Habsburg emperor and king of Hungary, Joseph II. allowed free religion practice and the defence of cemeteries where any denomination, thus also the Protestants, were allowed to set up grave-markers and also wooden grave posts.

The earliest sample of wooden grave posts comes from Kozmatelke in Transylvania from 1661 where a wooden grave-marker was set up on the grave of the Transylvanian prince Ákos Barcsay. Another early date comes from Nyárádszentanna in Székely land, near the River Nyárád (East-Transylvania) from 1678 where a wooden grave-marker called "fejefelettvalófa" was mentioned (Balassa, 1989). In the 18th century, several data are known concerning wooden grave-markers. In Nagykörös, a wooden grave-marker called "fejéhezvalófa" was set upon the grave mound of a servant in 1739. In Kecskemét, a wooden grave-marker called 
"fejéhezvalófa" was mentioned in 1755, and in Szabadszállás, another one called "Fötölvalófa" was carved in 1760. In Nagykörös, the respectable Reformed pastor passed away in January 1759, the burial expenses were covered by the town council, and they had a wooden grave post carved. The respectable notary of Nagykörös, Mihály Cseh was buried in 1771 on public expenses, thus these expenses were registered in the accounts of the town: "György Kállai was paid for making the coffin, carving the Epitaph and painting the wooden grave post, János Szattmári was paid for carving the wooden grave post". The accountant of the town paid "Péter Csontos for making the corner element and iron fasteners of the Epitaph". The grave edifice looked like a charnel-house. The special appellation of wooden grave posts occurs in 1803, too. The late chief justice of Nagykörös, Honorable and Noble Lajos Nyáregyházi Nyáry passed away and his funeral expenses were covered by the town council, too. The accounts give detailed information: "According to the decision of the Honourable Town Council wage was paid to the carpenter Istvány Elek for making the coffin and for painting the wooden gravemarker for the late Lajos Nyáry" (Archives of the National Archives in Pest County "Books of Account of the Honourable Gergely Patonay, Second Judge of the town Nagy Körös"1803/4). It is a point of interest in this case that the text refers to the ornamentation of the coffin; it was stud with 2,500 fine nails with bright heads. A painted wooden grave post a so called "föfa" (head wood) was set up.

In the Middle Ages, high-ranking aristocrats had ceremonial funerals with full military honours. Historical data still in existence demonstrate that at the funerals of Roman Catholic or Protestant aristocrats of rank also an elaborately carved, "gold-painted wooden epitaph" with a text honouring the deceased person was carried in the funeral procession together with signs of dignity like (carved gold-painted wooden court of arms, gilded broadsword, gilded bleeders, gilded helmet with feather, and gilded banner). At the end of the funeral, the epitaph was fastened on the church wall above the grave (Radvánszky, 1879).

The epitaph is in reality a memorial sign. At the funerals of common people, the epitaph was turned into a grave-marker, thus it had an independent function, i.e., that of a wooden grave post.

Hence, the epitaph was a kind of carved and painted wooden board, a real grave-marker. The simple grave-markers carved from a board, which can be found in the cemeteries of common people, were called at some places epitaph "epitafa" (memorial grave-marker).It was recorded that in the country town, Abony, the Roman Catholics broke into the Protestant cemetery at the night of Good Friday in 1741 because of religious discord and "they carried away the epitaphs and burnt them" (Balogh, 1975, p. 116.). In relation to a witchcraft trial in 1768, the following came to light: A woman, named Zsuzsanna Gorzsás, committed the sin of witchcraft in the town of Karcag (in the middle of the region Great-Cumania, i.e., Nagykunság), because she prepared charm from parts of the human body, which she burnt to ashes. If a robber or a thief had had the ashes on themselves, they could have avoided punishment, further on, if they had been imprisoned they would have escaped or "if they had been caught no legal action could have been taken against them". At dawn of a spring day, the accused woman and her daughter went to the gallows in Karcag and she cut off the "splinter bone" and "the genitals" of György Nagy whose body was hanging there. She also collected some other bones which were lying there. She had "one epitaph board brought from the Reformed cemetery, made fire and burnt the bones into ashes” (Novák, 2011, pp. 121-122).

The word epitaph (epitafa) did not subsist as a grave-marker either in Abony or in Karcag in the subsequent centuries (19th and 20th centuries). In Abony (Pest County), bulky posts with a narrow roundish shape on the top (gombosfa) were carved and decorated with fine motifs. In Karcag (the region Great-Cumania, i.e., Nagykunság), the wooden grave posts were not richly ornamented; however, the grave posts were made of 
bulky wooden pillars of imposing size. The memory of the epitaph as grave-marker subsisted in Ordas (BácsKiskun County) near the River Danube where the richly carved grave post with a narrow roundish shape at the top was still called epitaph, i.e., "epitafa" in the 20th century (Novák, 1978).

Both the appellations "fötölvalófa", "fütülvalófa", "fejéhezvalófa", and "gombfa", "gombosfa" spread widely among the Hungarians in the Carpathian basin in the 19th and 20th centuries; the former one meaning a grave-marker at the head-side of the grave, and the latter one meaning an epitaph with a narrow roundish shape at the top. The term "gombosfa" can be looked upon as the result of a stylistic development. An example of this can be found in Nagykörös. As long as in the 18th century and at the beginning of the 19th century, the appellations "fejefa", "fejéhezvalófa", and "fötölvalófa" were used; from the first half of the 19th century, the term "gombosfa" was in general use. The earliest allusion to it occurred in 1839 among the funeral expenses of András Erdei where five forints were paid for "making the coffin and the "gombosfa", i.e., grave post with a narrow roundish shape at the top (Novák, 1982; Malonyay, 1907). Also, the act Nr. VIII/1846 of the School Regulations of the Reformed secondary grammar school mentions wooden grave-markers: "It is forbidden for the pupils to insult gombosfa, i.e., grave-posts with a narrow roundish shape at the top and gravestones [...]" (Ádám \& Joó, 1896, p. 115).

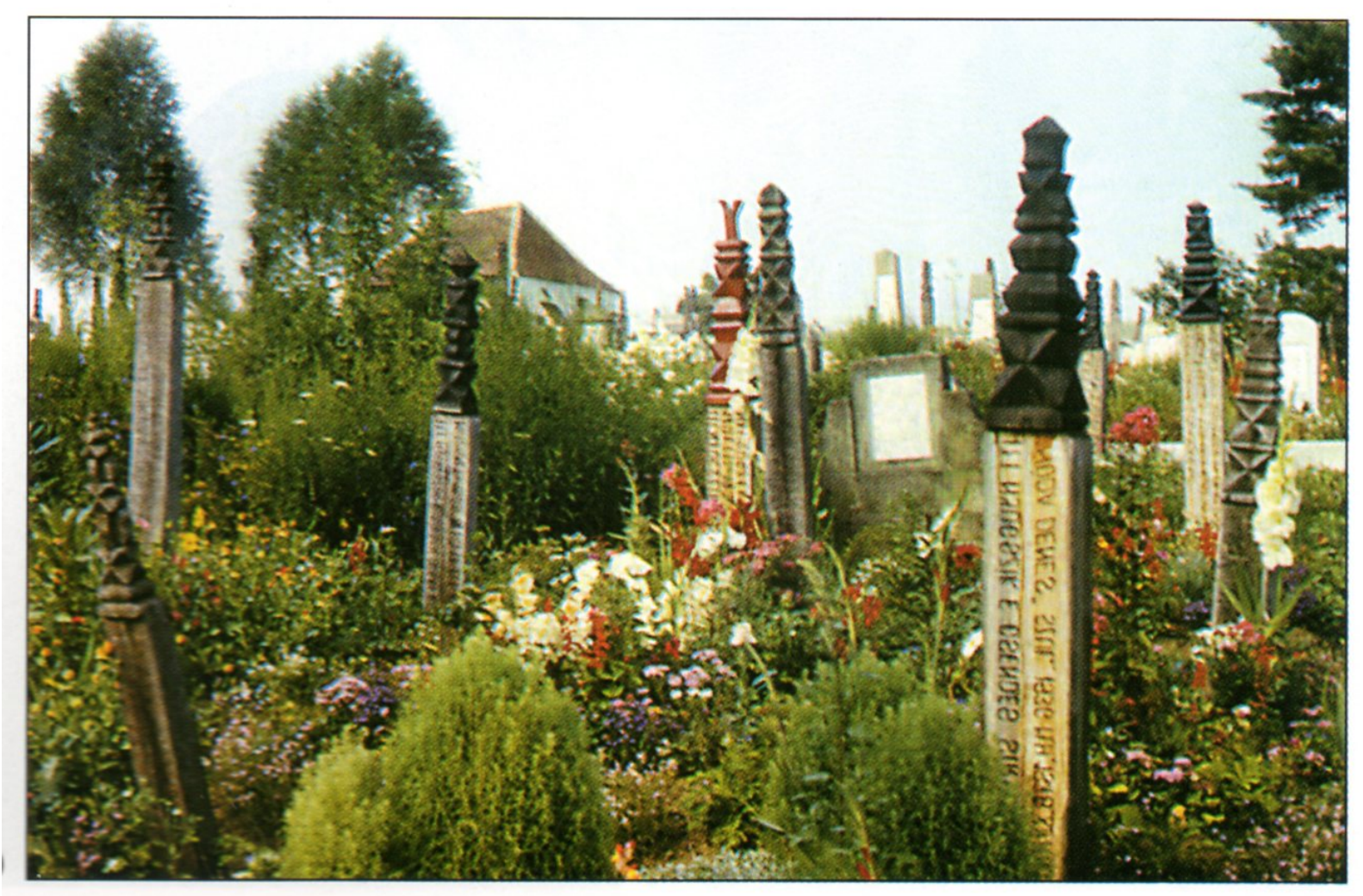

Figure 6. Knob-grave posts-Apáca. 


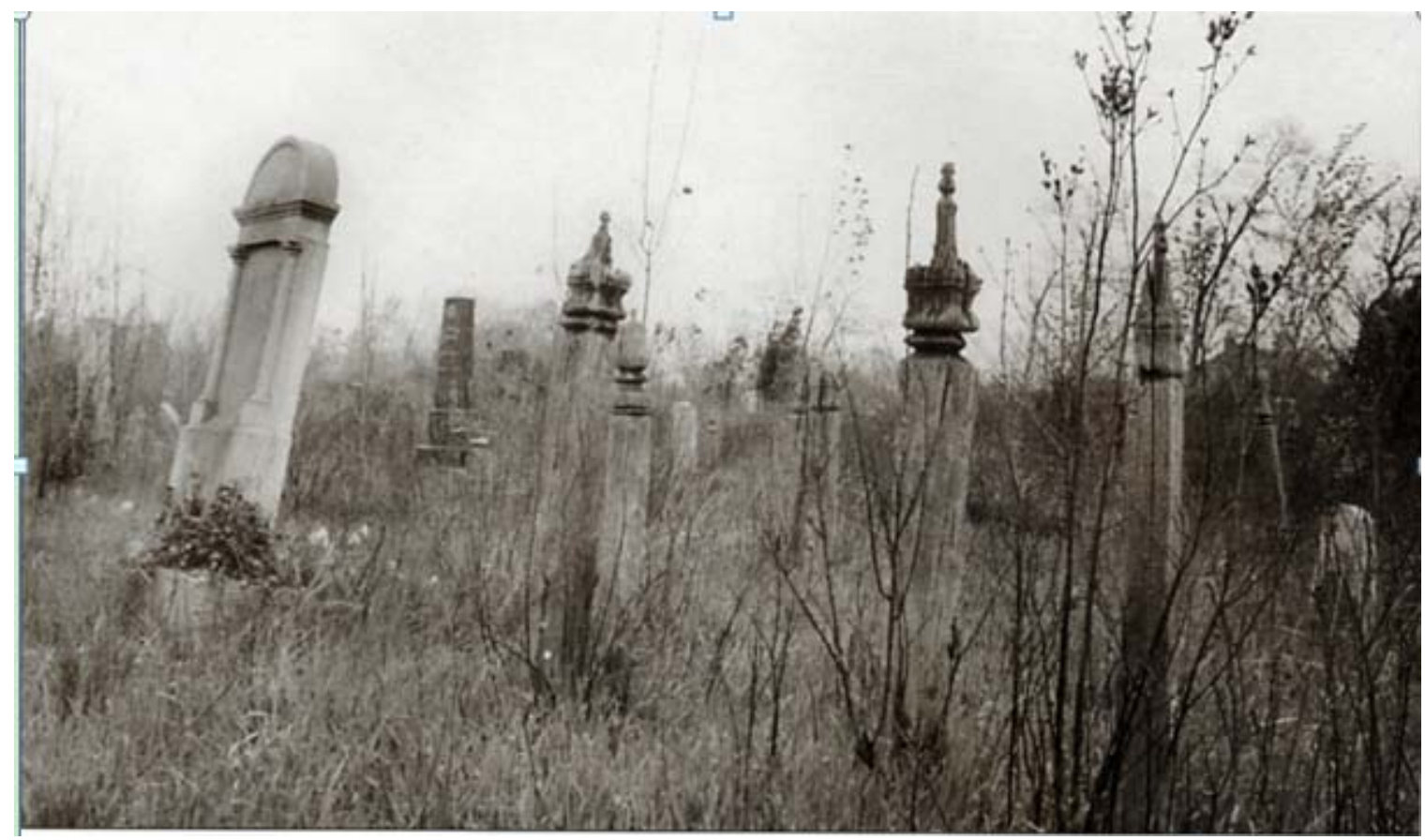

Figure 7. Knob-grave posts - Dömsöd.

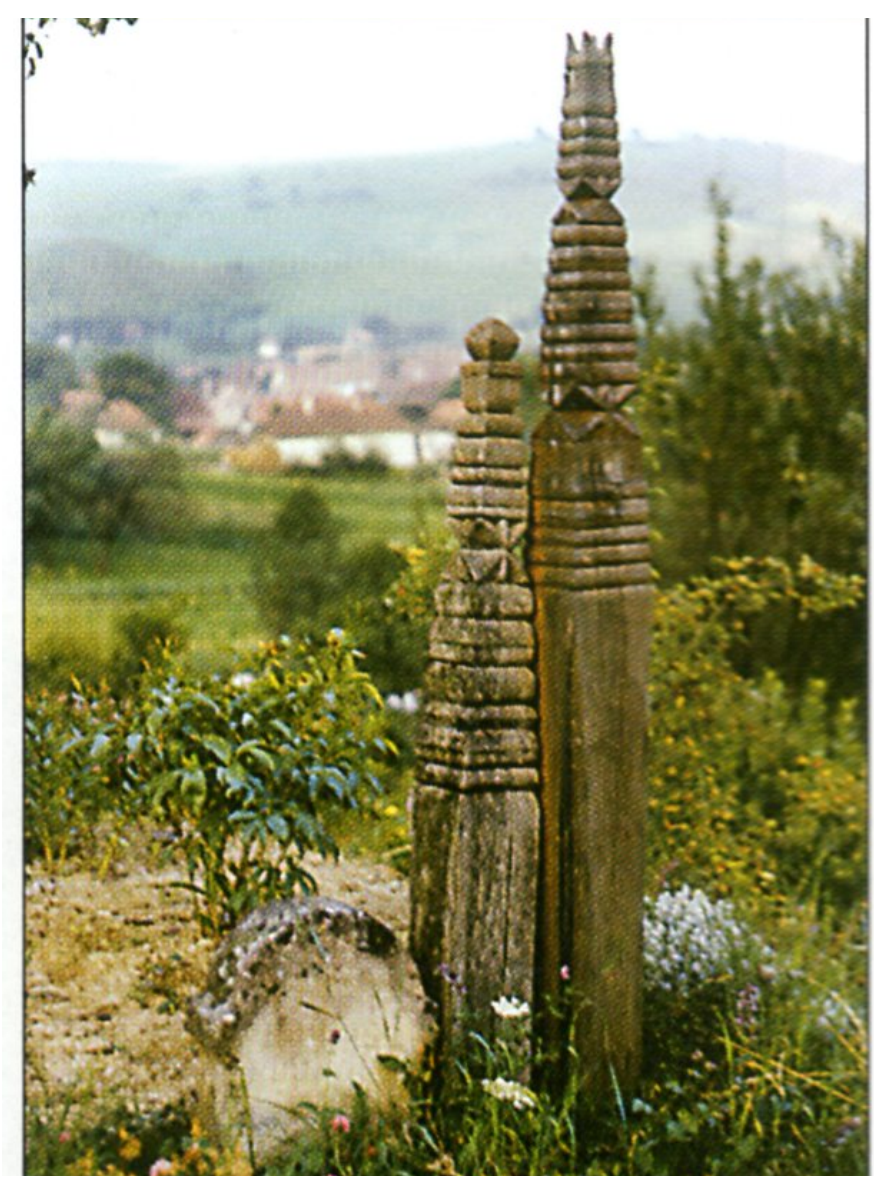

Figure 8. Knob-grave posts of a married couple (wife-husband)-Erdőfüle. 


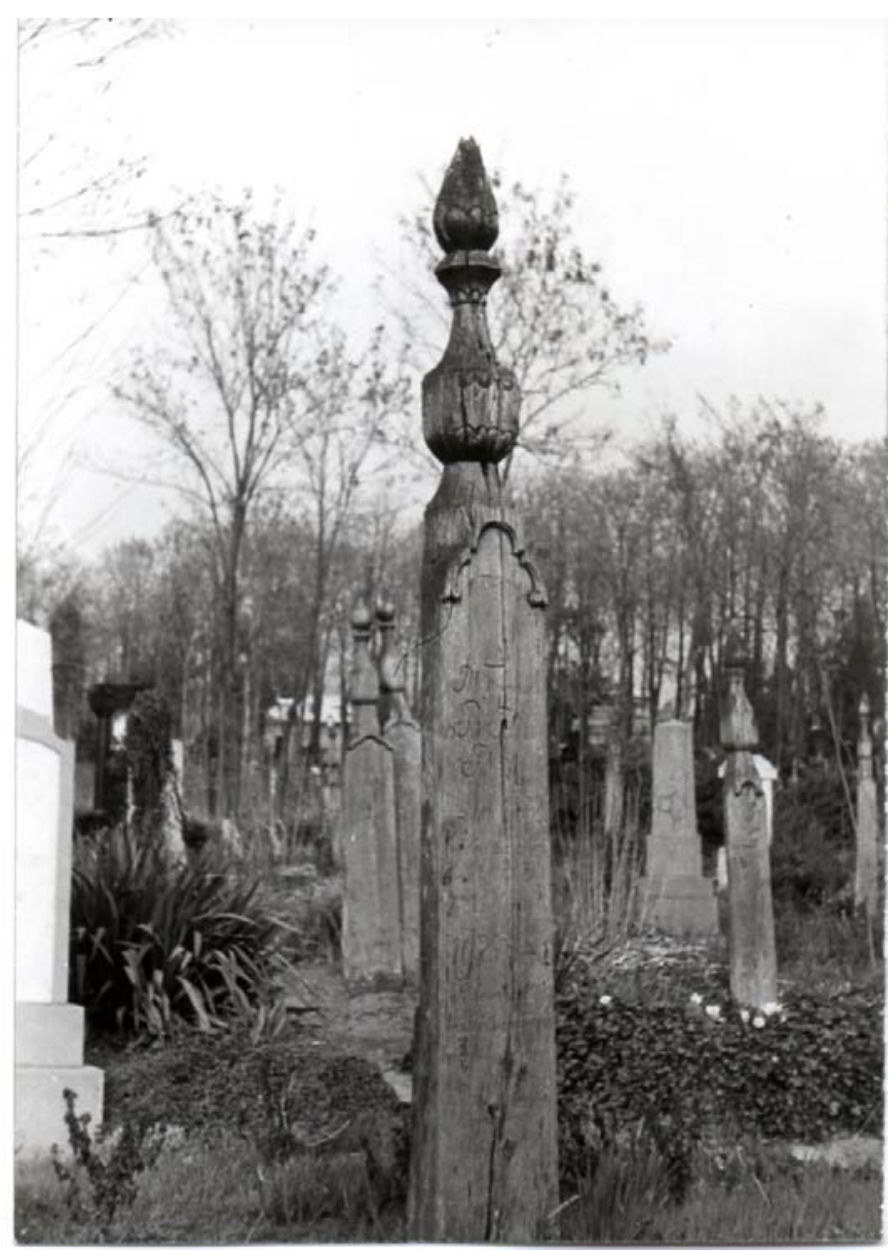

Figure 9. Knob-grave posts -Nagykőrös. 


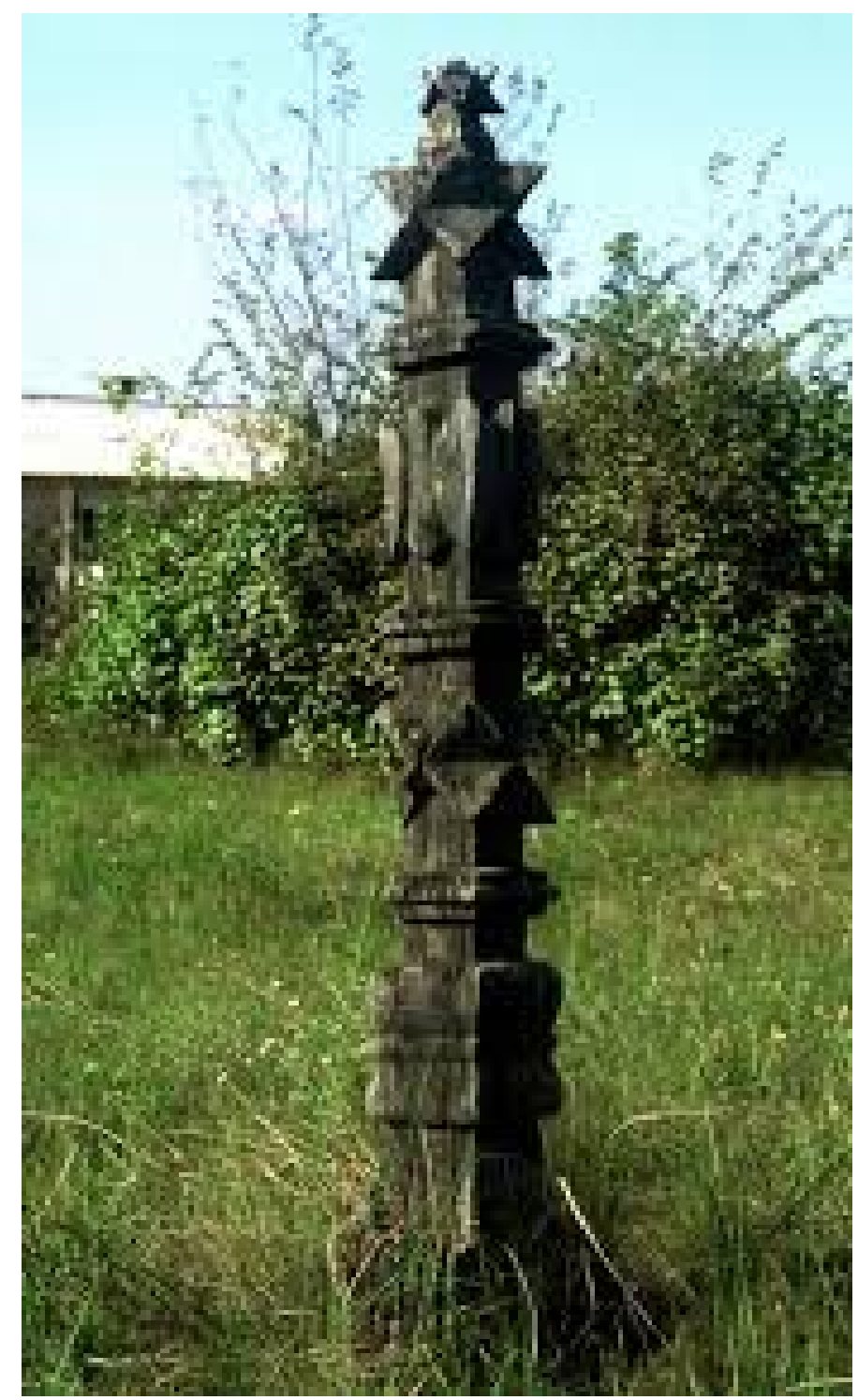

Figure 10. Knob-grave-post (tree of life symbol) - Irsa (Albertirsa).

The earliest carved wooden grave-markers come from the middle of the 19th century. A section plan of the country town Kecskemét shows the Reformed cemetery where grave-posts with a narrow roundish shape can be seen on the sepulchral mounds (Vahot, 1856; Novák, 1984).

Also, a peculiar zoomorphic, i.e., horse-like or foal-like motif can be found among the forms on wooden grave posts. Wooden grave posts with this peculiar motif were found only in Kalotaszeg. They are alliable only with the Transylvanian equestrian-nomad tradition. The horse (foal)-shape decoration of the upper part of the wooden grave posts remind us of ancient, nomad, Tartar traditions (see Figure 11) (It has to be mentioned here that after the attacks by the Turks and the Tartars in the middle of the 17th century [1661], some Tartarian population remained in Hungary and melted in the Hungarian society.) (Malonyay, 1907; Novák, 2005). Recent research has shown that some Aphgan tribes have zoomorphic grave-markers, too. (Dupree, 1980). 


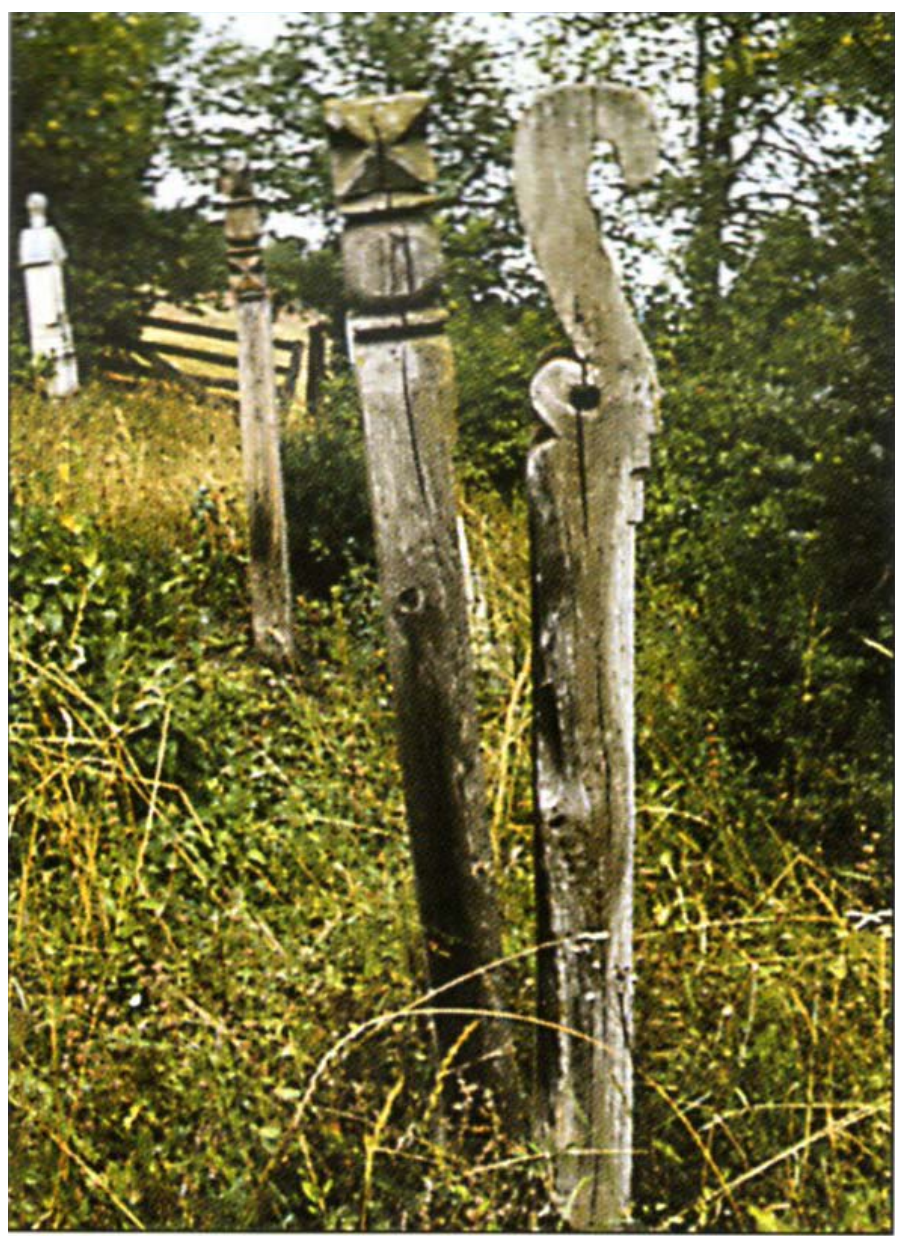

Figure 11. Zoomorphic and knob grave posts -Kalotadámos.

The last third of the 19th century is the heyday of grave-marker ornamentation. After the Austrian absolutism, the oppression had been over, rising national identity created the heyday of folk art following the Compromise between Austria and Hungary in 1867 (the establishment of the Austrian-Hungarian Monarchy). The anthropomorphic and richly carved traditional wooden grave-markers are beautiful examples of this.

\section{“Kopjafa”, i.e., wooden commemorative column}

The term "kopjafa", i.e., wooden headboard had spread in the common language and then appeared in the 20th century relating to national Romanticism and the centuries-old, Hungarian historical traditions.

The "kopja", i.e., the spear, which was an essential accessory of mediaeval sepulchral ceremony in the case of high-ranking aristocrats, was usually stuck into the grave mound. In 1561, an anonymous writer wrote a poem entitled "A Song to the Warriors of Gyula", in which the following was described: The bodies of the dead warriors were buried according to Hungarian custom. Their "kopja", i.e., spears were stuck into the mound on the head-side of their graves and the heads of the Turks, whom they had killed, were cut off and stuck onto the end of the spear.

Thus, the use of the "kopja" as a grave-marker was known in the Hungarian culture in the 16th century. The heads of the above mentioned Turkish warriors at the top of the poles visualised a real grave-marker, which resembled the anthropomorphic "gombosfa", i.e., an epitaph with a narrow roundish shape at the top or 
knob epitaph.

The "kopja", i.e., a spear proclaimed the heroism of the deceased warrior irrespective of his confession. A lot of beautiful memories of these burial customs are known of in Transylvania and in Székely land where both the Roman Catholic and Protestant aristocrats of rank had funerals with military honours. These funeral practices persisted well into the 19th century: The horse, which the Székely man of rank used to ride holding a "kopja" (i.e., spear furnished with flags) in one hand, was covered with black drapes. After the grave had been filled up the "kopja", i.e., spear furnished with flags was stuck into the ground showing that it was the grave of a man of rank.

The flagged spear is only a secondary grave-marker. The spear with a long shaft was not turned into a wooden grave-marker. When the funerals with military honours had disappeared, the use of the "gombfa", i.e., richly carved epitaphs with a narrow roundish shape at the top spread in some regions of Székely-land (Háromszék, Baróti-szék, and Bardócz-szék) in the second half of the 19th century. The lance furnished with flags disappeared from the cemeteries.

According to Viski (1910), the function of the spear holder underwent a functional change. Simultaneously with the decay of the period of warriors the flagged spear became shorter and its holder became more and more ornamental. The "gombosfa", i.e., a richly carved epitaph with a narrow roundish shape at the top came into being in this way. A small flag with a short flagstaff was stuck into the head of the anthropomorphic epitaph, thus referring to the old funerals with military honours (Viski, 1910).

This habit survived in the funeral rituals of young people in Kalotaszeg for the longest time. In the first place, marriageable girls and single young men were buried with great pageantry. They celebrated "the wedding of the dead person" in reality and also some motifs of the military honours were preserved. In Kalotaszeg, e.g., the dead girl was clad as a bride and the young man was clad as a bridegroom. The young people processing on both sides of the coffin were dressed as bride's maids, the young men were full-dressed, and they were holding colourful scarves and decorated flags in their hands. The young people prepared so called "three boughs" for the funeral. They wove a bridal wreath of the boughs of an ash tree and decorated it with a flower garland. It was carried at the head of the procession, and then it was stuck into the head of the anthropomorphic epitaph like the flagged lance that had been stuck into it in the old times. Also, the colourful scarves, like flags were fastened on the apex of the knob grave marker as it was done in Sztána in the region of Kalotaszeg (At the funeral of a young man colourful scarves were fixed on a wooden framework, which was in turn attached to the head of the anthropomorphic epitaph (Data collection by the author, 2002).

Flags played an important role in the course of funerals not only in Transylvania but also in some other regions of Hungary where noblemen lived even after the decay of the period of warriors in the 19th century. In 1844, the cemetery in Nagysimony in the County of Vas was mentioned. The inhabitants in Nagysimony were Lutherans, thus they used a cross instead of a wooden grave-marker. However, aristocrats had funerals with full military honours and a flagged pole was stuck into the grave-mound (Novák, 2005).

In regions far away from Transylvania and more precisely from Székely land funerals with military honours make it obvious that wooden crosses, wooden grave-markers, spears, and flagged spears used to exist simultaneously. The spear (kopja) demonstrated that the deceased person in the grave was high ranking; however, it did not function as an independent grave-marker. Thus, it is important to stress that the "kopja", i.e., the spear cannot be considered as a primary but rather as a secondary grave-marker. Consequently, we cannot speak about the "kopjafa", i.e., spear as a peculiar wooden grave-marker. 
Also, the poles on which the coffin was carried to the grave have to be examined in connection with the evolvement of the wooden grave-marker. In the case of the funerals of common people, the coffin was put on two or three poles and carried by four or six men to the graveyard. In a lot of regions, one of the three poles was stuck into the grave mound on the head side, marking the grave temporarily and the two others were stuck into the ground on the feet side. Later on, a gravestone or a column-shaped wooden grave-marker was set up and the pole on the head side was removed. However, the poles on the feet side of the grave might have become "feet grave-markers". The function of the poles on the feet side was modified. Some of them had the original length and were decorated, like in Magyargyerömonostor, County of Kolozs in Transsylvania. In a lot of cases, however, they became much higher; they were as high as the wooden grave-markers, like in Tiszaug, Tiszakürt in Tiszazug Region.

\section{Conclusions}

The author states that the characteristic grave-marker of the Hungarians is the richly carved wooden gravemarker that is characteristic of certain ethnic regions, villages, and country-towns, it is a Hungaricum. It is a peculiarity of the Hungarian folk culture. Various dialects have preserved various terminologies of wooden grave-markers; however, "kopjafa" (spear grave-marker/wooden headboard) cannot be found among them. The old weapon, the spear used to be an important part of the mediaeval ceremonial funerals; however, it had only a secondary function as a grave-marker. The spear furnished with flags and stuck into the grave mound proclaimed the battle honours of the deceased person. The carved wooden grave-marker, the anthropomorphic epitaph with a narrow roundish shape at the top ( $g o m b f a)$ is real sepulchres not only for high-ranking persons but also for common people.

Wooden grave-markers are local-specific. The ones in some villages or country towns, where Hungarian Reformed, Unitarian, and also Lutheran population lives, represent a characteristic grave-marker culture. These wooden grave-markers were prepared by local peasant handymen and they were masterpieces of folk art (Novák, 2005). The "kopjafa" is a carved wooden commemorative column. It is an artwork of carving folk art. Traditional motifs of wooden grave-markers, like stars, tulips, buttons, rings, and flower-stands are used to decorate the "kopjafa", i.e., wooden commemorative column.

These are not grave-markers but rather commemorative columns (neo epitaph), which as symbols keep the memory of historical events, like the site of defeat in Mohács in 1526, the memorial places of the war of independence in 1848 and 1849, and that of the revolution and war of independence in 1956. They express the common national identity with parts of Hungary, like Upper-Hungary (Slovakia), Sub-Carpathia (Ukraine), Transsylvania and Székely-land (Romania), and Bácska-Bánát (Voivodina, Serbia), which were torn away and allocated to neighbouring countries by the treaty of Trianon in 1920. In these regions, the commemorative columns serve as grave-markers at places, like in Roman Catholic graveyards, where their presence would not have been possible earlier (Juhász, 2005). 


\section{References}

Ádám, G., \& Joó, I. (1896). A Nagy-Körösi ev. ref. Fögymnasium története (The history of the evangelical reformed secondary grammar school).Nagy-Körös: Press of Ede Ottinger.

Altorjai, A. P. (1972). Metamorphosis transilvaniae. Budapest: Magyar Helikon.

Balassa, I. (1989). A magyar falvak temetői (Graveyards in Hungarian villages). Budapest: Corvina.

Balogh, S. (1975). Abony történeti és múvészeti emlékei (101450-1741) (Historical and artistic relics of Abony). Ceglédi Füzetek (Cegléd Booklets), 21.

Dupree, L. (1980). Afganistan(Afghanistan). Princetown N. J.: Princetown University Press.

Juhász, L. I. (2005). “Fábaróva, földbeütve...” A kopjafák/emlékoszlopok mint a szimbolikus térfoglalás eszközei a szlovákiai magyaroknál ("Carved in wood, stuck into the ground..." wooden headboards/commemorative columns as means of symbolic expansion of the Hungarians in Slovakia). Komárom-Dunaszerdahely: LiliumAurum.

Koczogh, Á. (1979). Főtülvalófák (Wooden grave-markers.). Confessio, III. Budapest, 84-101.

Kós. K. (1972). Népélet és néphagyomány (Folk life and folk tradition). Bukarest: Kriterion.

Malonyay, D. (1907). A kalotaszegi magyar nép müvészete. (The art of the Hungarian Folk in Kalotaszeg). Budapest: Franklin.

Novák, L. F. (1978). A Duna-Tisza köze temetöinek néprajza. (Ethnography of the cemeteries in the Danube-Tisza interfluve) Kecskemét: Museum Association of the County Bács-Kiskun. In: Cumania V. 2019-305. (eds.: Attila Horváth and Ede Solymos)

Novák, L. F. (1983). Sozialanthropologie der ungarischen Friedhöfe. Acta Ethnographica, 32, 123-160.

Novák, L. F. (1984). Fejfák a Duna-Tisza közén (Wooden grave-markers in the Danube-Tisza interfluve). Nagykőrös: Little Monographs of the János Arany Museum 2.

Novák, L. F. (1990). Il Cippo di Legno Nell' Europa dei Carpazi. Florence, Lares, LXVI (3), 385-395.

Novák, L. F. (2005). Fejfa monográfia (A monograph of wooden grave-markers). Nagykőrös: Little Monographs of the János Arany Museum 16.

Novák, L. F. (2011). Fejfa, kopja-fa (Wooden grave-markers, wooden headboards). In V. Románné Roxer - T. Varga (Eds.), $A f a$ a népi épitészetben régen és ma (Wood in folk architecture in old times and today, pp.119-134). Sopron: University of West Hungary Publishing- EMK Museum of Forestry, 119-135.

Novák, L. F. (2015) - Vallás, temető-temetés, sírjel. (Religion, cemetery-burial, grave-marker.) In. Hódmezővásárhely néprajza. Vol.2. (Ethnography of Hódmezővásárhely (editor in chief: László Ferenc Novák, eds. Vera Nagy, Tibor Szenti) Hódmezővásárhely: László Németh Library, pp. 1041-1078.

Orbán, B. (1868). A Székelyföld leírása I (Description of Székely-land I). Retrieved from http://mek.oszk.hu/04800/04804/html/index.htm

Orbán, B. (1870). A Székelyföld leirása IV (Description of Székely-land IV). Retrieved from http://mek.oszk.hu/04800/04804/html/346.html

Radvánszky, B. (1879). Magyar családélet és háztartás a XVI. és XVII. században. (Hungarian family life and housekeeping) Vol. 3. Budapest: Hungarian Academy of Science

Solymossy, S. (1930). Ösi fejfaformák népünknél (Ancient forms of wooden grave-markers of the Hungarian Nation). Ethnographia, XLI, 65-84.

Vahot, I. (1856). Kecskemét és kecskeméti puszták. (Kecskemét and the surrounding plains) Magyarország és Erdély képekben I. (Pictures of Hungary and Transylvania. Vol.1. Pest: Press of Gusztáv Emich.

Viski, K. (1910). Mi a kopjafa? (What do we call "kopjafa," i.e., wooden commemorative column?) Néprajzi Értesitő, XI (3-4), 221-224. 